\title{
Aerial Orthophoto and Airborne Laser Scanning as Monitoring Tools for Land Cover Dynamics: A Case Study from the Milicz Forest District (Poland)
}

\author{
Marta Szostak, ${ }^{1}$ Piotr Wezyk, ${ }^{1}$ and Piotr Tompalski ${ }^{1}$
}

\begin{abstract}
The paper presents the results from the study concerning the application of airborne laser scanning (ALS) data and derived raster products like the digital surface model (DSM) and the digital terrain model (DTM) for the assessment of the degree of change of the land use based on the forest succession example. Simultaneously, an automated method of ALS data processing was developed based on the normalized (nDSM) and cadastral GIS information. Besides delivering precise information on forest succession, ALS technology is an excellent tool for time-changes spatial analyses. Usage of the ALS data can support the image interpretation process decreasing the subjectivity of the operator. In parallel, a manual vectorization and object classification (objectbased image analysis-OBIA) were performed; both based on aerial orthophoto and ALS data. By using integrated ALS point clouds and digital aerial images, one can obtain fast OBIA processing and the determination of areas where the land cover has changed. The Milicz District (central west part of Poland) was chosen as the test site where ALS was to be performed in 2007, together with the digital aerial photos (Vexcel camera; pixel $0.15 \mathrm{~m}$; CIR). The aerial photos were then processed to a CIR orthophoto. The area of study consisted of 68 private parcels (some of them were abandoned; $68.57 \mathrm{ha}$; scanned cadastral maps from the local survey office; land use information) in the direct neighbourhood of the State Forest, on which a forest succession could often be observed. The operator vectorized forest (trees and shrubs) succession areas on the 2D CIR orthophoto. They were then compared with the results from the OBIA and GIS analysis, based on the normalized digital surface model. The results showed that areas with high vegetation cover were three times larger than the official land cover database (cadastral maps).
\end{abstract}

Key words: CIR aerial orthophoto, airborne laser scanning (ALS), object based image analysis (OBIA), GIS analysis, digital surface model (DSM), digital terrain model (DTM), secondary forest succession.

1 Laboratory of Geomatics, Department of Forest Ecology, Faculty of Forestry, University of Agriculture in Krakow, Krakow, Poland. E-mail: rlszosta@cyf-kr.edu.pl; rlwezyk@cyf-kr.edu.pl; piotr.tompalski@ur.krakow.pl

\section{Introduction}

The most common quantitative measurement of the landscape is the type of land use. These days, the most common data source for land use are satellite images, aerial photographs and thematic maps. Another source of the data can also be the digital land cadastre (LOwICKI, 2008). The importance of monitoring land use changes to support regional development programs is recognized by the Commission of the European Communities and the European Environment Agency (Commission of the European Communities, 1994). European environmental programs based on remote sensing data carried out in 1990 (Corine Land Cover) are designed to track the dynamics of transformation of the structure of land cover (land use) in the individual EU member states. Subsequent cycles of the project: CLC1990, CLC2000, and CLC2006 have been used to create thematic maps relevant to satellite imagery from LANDSAT and SPOT.

One of the most important landscape geocomponents are forests. Beyond the important economic function (timber production), forests increase biodiversity and play an important role in protecting the soil and water resources. They help shape the quality of life by having an effect on the local climate and beauty of the region. The last official report about the total area of Polish forests shows that $29.2 \%$ of the area of Poland is covered by forests (in our climatic and geographical zone forests are the most natural formation). This percentage differs in various regions, from 21 to $49 \%$. The forest area per person in Poland is only 0.24 ha and is one of the lowest in Europe. Approximately $81.5 \%$ of forests in Poland are publically owned (Central Statistical Office GUS, 2010). The official map of Polish forests is not 
up-to-date since it does not include the areas of uncontrolled forest successions (FINEGAN, 1984; Glenn-Lewin and van der MaArel, 1992; Fry and SARLÖV-HerLin, 1997) which occur on fallow land. The problems concerning the land cover changes and forest succession are similar to those of other countries or regions in Central Eastern Europe (PrÉvosto et al., 2011; BALDOCK et al., 1996; FRY and SARLÖVHerlin, 1997; Lindner et al., 1996). This situation calls for an effort to monitor land cover dynamics using remote sensing and GIS technology (HALL et al., 1991; Bergen and Dronova, 2007). It can be accessed from both the manual interpretations of digital aerial images (WEZYK and Pyrkosz, 1999) and high-resolution satellite images (WEZYK and DE KoK, 2005) or airborne laser scanning data (WezYK et al., 2009).

The topic of the article refers to the assessment of the process of changes in the land cover (land use), mainly including secondary forest succession on arable land based on digital multispectral airborne orthophotos and the airborne laser scanning (ALS) point cloud data. Airborne laser scanning, a type of light detection and ranging (LiDAR) technology, is a modern remote sensing technology used for collecting 3D information (point clouds) and providing precise information about terrain elevation and vegetation structure for large areas (ANDERSEn et al., 2006; Нyyppä et al., 2004; Holmgren and Jonsson, 2004; McGaughey et al., 2004). Acquired 3D point clouds with precise XYZ coordinates constitute the geometric information, and additional information like intensity or echo number is the descriptive data. The ALS technology allows for an exact and quick obtainment of information on terrain elevation (digital terrain modelDTM) and the objects on the terrain surface (digital surface model-DSM). Proper methods of filtration and classification of the point cloud lead to generating very precise DTMs, DSMs and normalized digital surface models (nDSM) representing the approximated surface objects (Axelsson, 2000; WEZYK et al., 2008a, 2010). ALS data has many applications in monitoring land cover dynamics and forest management, but can also be used in ecological research on biomass or carbon sequestration (Goluch et al., 2009; Hollaus et al., 2009; NyströM et al., 2012; WeZYк et al., 2012c). Modern geoinformation technologies such as LiDAR or satellite imagery (VHRS) can be used for mapping the land cover (HöFle and Hollaus, 2010; Rutzinger et al., 2007) and characterizing the vertical structure of vegetation (EwiJk et al., 2009; Наsнімото et al., 2004; LeFsKy et al., 2002; MüCKE et al., 2010; WEZYK et al. 2008b).

The paper presents an attempt to automate the ALS point cloud processing, integrated with the spatial analyses in GIS. Both, ALS and image data were also subdued to the process of object based image analysis (OBIA). OBIA was selected for the study because this type of image classification is mainly used in the world's leading research centres involved in the processing of remote sensing images (HAY et al., 2005; DE KoK et al, 2008; BlaschKe, 2010). OBIA technology uses both the traditional approach of pixel classification, as well as the logical connections and the geometry of the groups of pixels making specific forms (elements of texture). The use of 3D point clouds from laser scanners, particularly in the aspect of their integration with the multispectral information originating from digital cameras, allows for processing the OBIA type computer programs (eCognition; Trimble GeoSpatial) to significantly enhance the process of image interpretation and diminishing the subjectivity of the operator. The main goal of the presented paper is to identify opportunities where the automatic approach can be used for ALS point cloud data processing and object-based image analyses, when assessing land use changes in Poland.

\section{Study Area}

The study was conducted in the central west part of Poland, in the Dolnoslaskie Voivodeship; the District of Milicz situated in the valley of the River Barycz (the site of the largest landscape park in Poland). The landscape, for the most part, consists of diverse forests and ponds. Forests in this region belong to the Forest District of Milicz and are owned by the Wroclaw Regional Directorate of the Polish State Forest National Holding. The selected area of study (Fig. 1) was the one where the most dynamic 


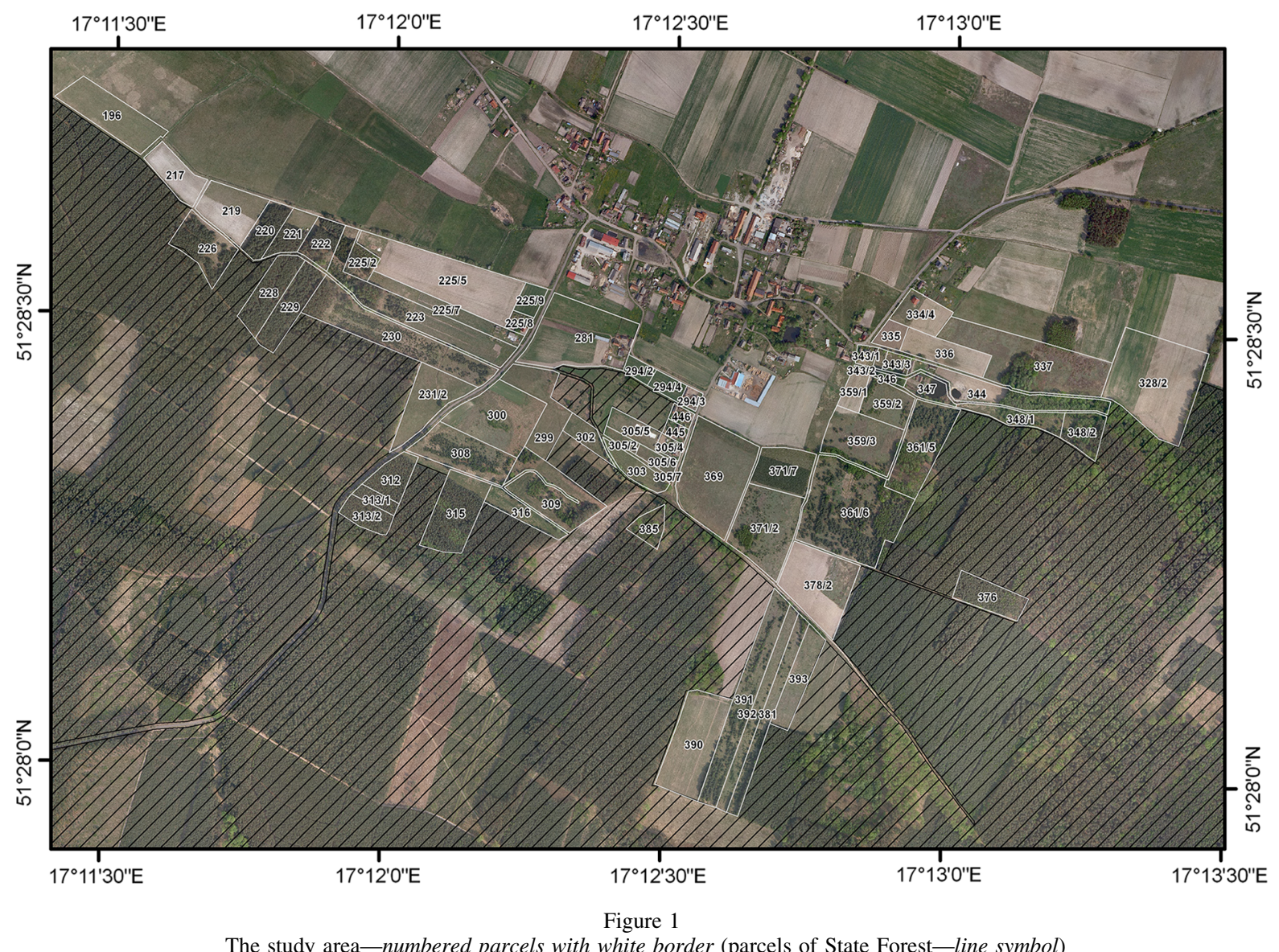

changes in land use, especially uncontrolled secondary forest succession, were observed.

For the Milicz Forest District, the remote sensing data were obtained for the project by financial support from the General Polish State Forests Directorate in the years 2006-2008. There were different GI technologies (airborne and terrestrial laser scanning, photogrammetry) tested in terms of their usefulness in forest inventory (STERENCZAK, 2009; WEZYK et al., 2007, 2008b). The airborne campaign was carried out in July 2007 using the TopoSys glass fibber scanner Falcon II with a so-called "swing mode". The mean relative height of flight was about $550 \mathrm{~m}$ above the ground. The mean point density was ca. $14 \mathrm{pts} / \mathrm{m}^{2}$ (varied from 9 to $18 \mathrm{pts}$ ). Single scans were delivered in ASCII format (raw data) as well as raster format (DSM and DTM). The aerial photographs were captured using the Vexcel XP camera in May 2007.

The presented area of study consisted of 68 cadastral parcels (total area equal to 68.57 ha; mean parcel area of $1.01 \mathrm{ha}$ ). Areas where secondary forest succession was below $5 \%$ or where the area was built-up were excluded from the study. The remaining parcels were called test areas (32 cadastral plots; total: $40.5 \mathrm{ha}$ ). In the test area, the following land-use classes occurred:

- Arable land (A): total area of 27.93 ha, i.e. $69.0 \%$ of test area,

- Forest (F): forest, woodland and shrubs having 6.23 ha; $15.4 \%$,

- Meadow (M): 2.05 ha; $5.1 \%$, and

- Pasture (P): 4.29 ha; $10.6 \%$.

\section{Materials and Methods}

The following remote sensing data (imagery + ALS data) and cartographic materials were applied in the study: 
a) imagery data (2007);

- digital aerial photos (Vexcel XP camera; GSD 0.15 m; bands: R, G, B, NIR). The aerial photos were processed in RGB orthophotos (GSD $0.25 \mathrm{~m})$,

- CIR- "true orthophoto" as products of the linear scanner TopoSys (GSD $0.25 \mathrm{~m}$ ),

b) ALS data-point clouds (TopoSys 2007 Falcon II; 14 points $/ \mathrm{m}^{2}$; FE/LE). Filtering, ground classification, models: DTM, DSM, nDSM,

c) cadastral data (parcels + land use) obtained from the District Centre of Surveying and Cartography Documentation in Milicz (data of 30 December 2003).

The selected area of study was one where the most dynamic changes in land use were observed. These were cadastral parcels in the vicinity of forest grounds (a buffer zone of approximately $200 \mathrm{~m}$ ) making the property a State Forest (Forest Division Milicz, Pracze, Fig. 1). This area was characterized by frequent cases of secondary succession of foresttype vegetation (trees and shrubs) occurring mainly on arable land and grass areas (meadows, pastures).

Three different methods of data input and processing were used:

- manual (on-screen) vectorization of the secondary forest succession areas (trees and shrubs): orthophoto (RGB) and true orthophoto (RGB + NIR),

- GIS spatial analyses based on the normalized digital surface model (nDSM) form ALS point cloud data,

- object based image analysis (OBIA) based on the ALS and image data.

The purpose of manual vectorization was to determine the areas affected by the succession of secondary forest vegetation within the subsequent cadastral parcels using traditional means of photointerpretation of airborne orthophotos (orthophotos and "true orthophotos" from a linear scanner). This step was carried out in an ArcGIS (Esri) environment. The operator vectorized high vegetation as the outlines of trees, bearing in mind that in the orthophoto an improper situation (shifting) of the tops of high trees can occur depending on the distance from the main point in the image.
Despite this, the automation process of ALS point cloud was made to determine the borders of the vegetation cover (land use). The first stage was a preprocessing of ALS data and tiling it into squares of $500 \times 500 \mathrm{~m}$. These tiles were then processed in TerraScan (Terrasolid Ltd.) with user-defined macros to classify points to the ground class. This class was used to generate DTM by the active TIN method (Axelsson, 2000). This model was necessary for the normalization of ALS point clouds which is a process of converting the height of trees and buildings to their relative values. Normalized ALS point clouds were then subjected to algorithms (FUSION software; McGoughey, 2007) generating surfaces approximated by the highest points of the first laser reflections (nDSM); preserving local maxima and minima by applying proper smoothening filters. The size of the approximated nDSM pixel was set to $0.25 \mathrm{~m}$. The studies were carried out in three versions of $\mathrm{nDSM}$ pixel " $Z$ " values: above $1.0,2.0$, and $3.0 \mathrm{~m}$, representing various heights of secondary forest vegetation above the ground. The automation of the GIS-based analysis of nDSM was performed in ArcGIS Model Builder (WEZYK et al., 2009; Fig. 2), containing steps including map algebra and zonal statistics.

A further step of the work was object classification based on cadastral data, image data, and the processed ALS point clouds (nDSM). The scheme of the OBIA processing (eCognition; Trimble Geospatial) is presented in Fig. 3. Processing using the OBIA approach is based not on single pixels, but on objects-groups of pixels representing various features. In the first step, the pixels are segmented into objects, then the objects are assigned to land cover classes defined by the user. In fact, the process can be expanded on and can consist of many steps of reshaping, resegmentation, and reclassifying of the initially created objects. This may seem complicated, but it allows the creation of so-called rule-sets for processing large amounts of datasets without any user interaction (GAO and MAS, 2008). Object-based image analysis can be used to process different types of spatial data like raster satellite images and vector GIS data, as well as ALS point clouds. The OBIA approach was started by distinguishing "vegetation" and "nonvegetation" classes using spectral information (NDVI value). Then the "vegetation" class was 


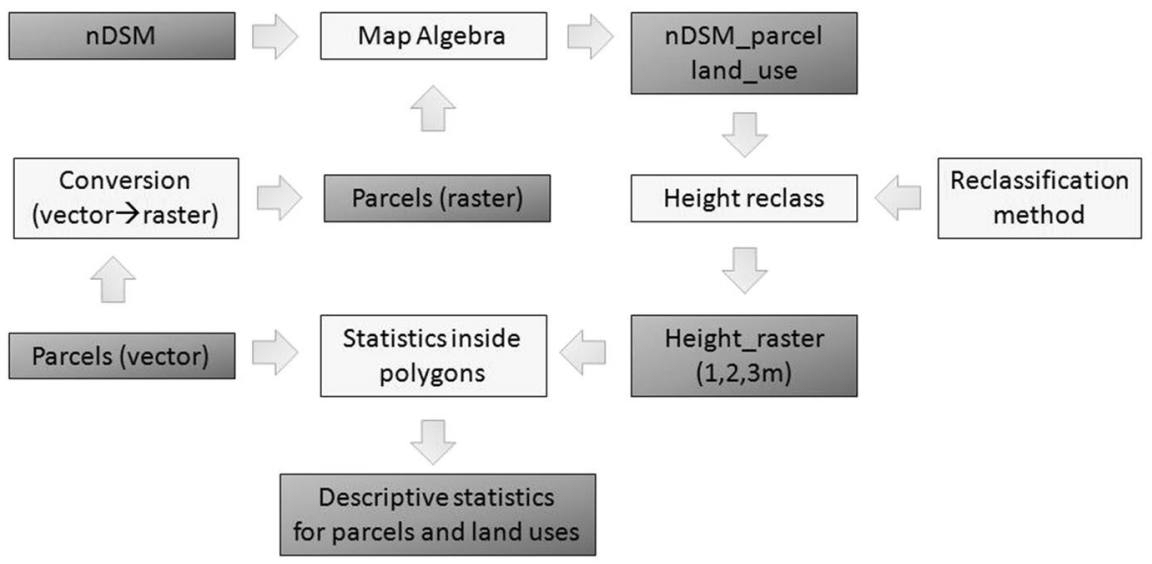

Figure 2

A model of the automatic processing of normalized ALS point cloud and cadastral data with GIS analyses

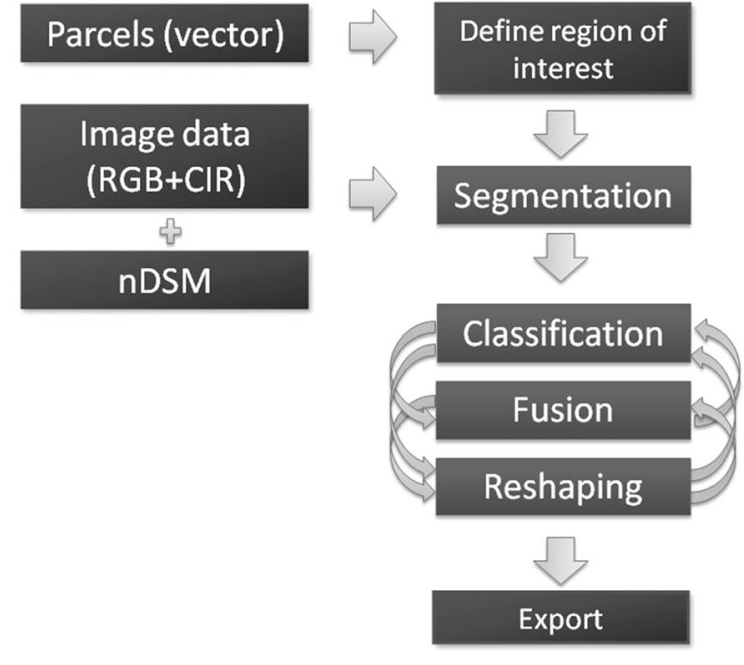

Figure 3

The scheme of object based image analysis (OBIA)

processed using the information stored in digital height models (nDSM) leading to precise borders of low and high vegetation. The minimum sampling unit was equal to $4 \mathrm{~m}^{2}$.

\section{Results and Discussion}

The borders of the secondary forest succession determined in the process of photointerpretation by the operator "on screen" with digital airborne orthophotos (RGB and CIR), and the nDSM are presented below (Fig. 4).
Automatic determination of the borders of class "vegetation" was carried out step-by-step, applying object based classification (Fig. 5). The process of classification was carried out using the cadastral parcels as the borders of analysed area. For each parcel the vegetated areas were classified by using the multiresolution segmentation algorithm (eCognition) based on the single multispectral bands (R, G, B, NIR) and NDVI layer. "High vegetation" was classified afterwards using the geometrical information (height) stored in nDSM layer. This step was performed using a given threshold value of $1.0 \mathrm{~m}$ to distinguish between "low" and "high" vegetation classes within the general "vegetation" class. The final objects representing the high vegetation within the borders of each parcel were a subject of automatic revision to point out areas of potential misclassification due to inaccurate parcel borders. The final result of the carried out object classification was compared to the results of the spatial GIS analyses, mainly based on the transformed ALS point cloud (Fig. 6).

The result of the "on screen" photointerpretation, the GIS analysis nDSM, and the OBIA approach (Table 1) were very similar compared to the assigned classes and the area of distinguished objects. This can also be observed in Fig. 6. This means that the automatic method of delineating "high vegetation" can be used on large areas and provide very accurate results. The analyzed area revealed that the "Forest" (F) class having an area three times larger than the 

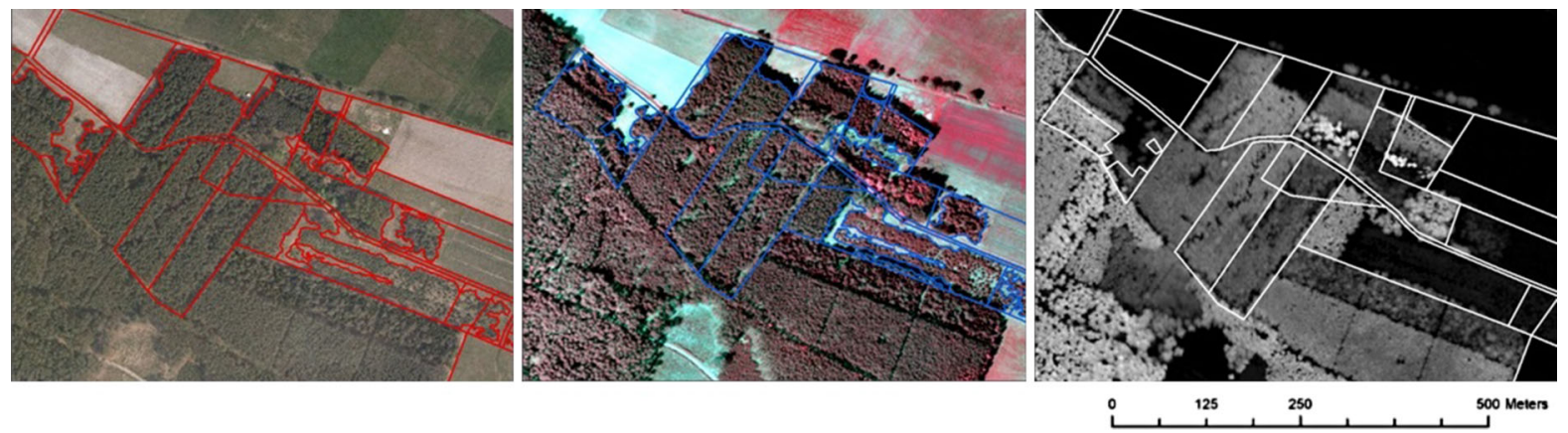

Figure 4

The result of the process of photointerpretation and on-screen vectorization made by the operator on airborne orthophotos and nDSM (from the left: RGB orthophoto, true orthophoto CIR and nDSM)
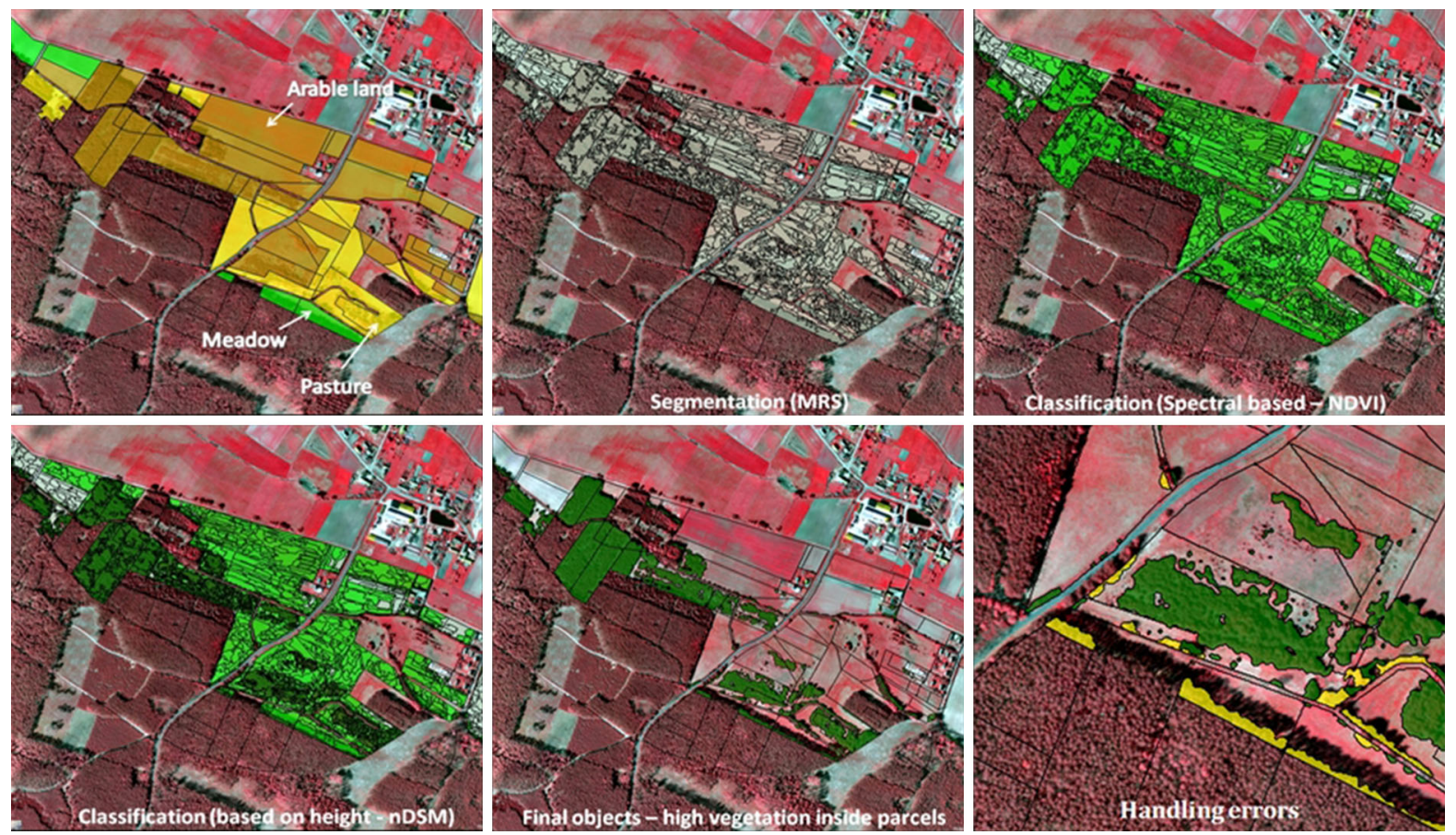

Figure 5

Steps of the OBIA

reference data stored in the cadastral databases (District Centre of Surveying and Cartography Documentation in Milicz; PODGiK). The "Forest" (F) class replaced the "Arable land" (A) -11.06 ha $(27.3 \%)$, "Pastures" (P) -1.77 ha $(4.4 \%)$ and "Meadows" (M) -0.68 ha $(1.7 \%)$. The inventory based on the remote sensing data showed that $81.9 \%$ of the "Forest" (F) class was formed from arable land (A), $13.1 \%$ from "Pastures" (P) and $5.0 \%$ from "Meadows" (M). This confirms the problem commonly mentioned among the secondary forest succession on abandoned arable land where the agriculture has been stopped (WEZYK and DE KOK, 2005; Bowen et al., 2007; Oikonomakis and Ganatsas, 2012; RusKule et al., 2012; SusYAN et al., 2011; ZhANG, 2005).

The goal of the paper was to define the possibilities for detecting vegetation classes in an automatic way using ALS and the image data. The authors proved that it is possible by using GIS spatial analysis 

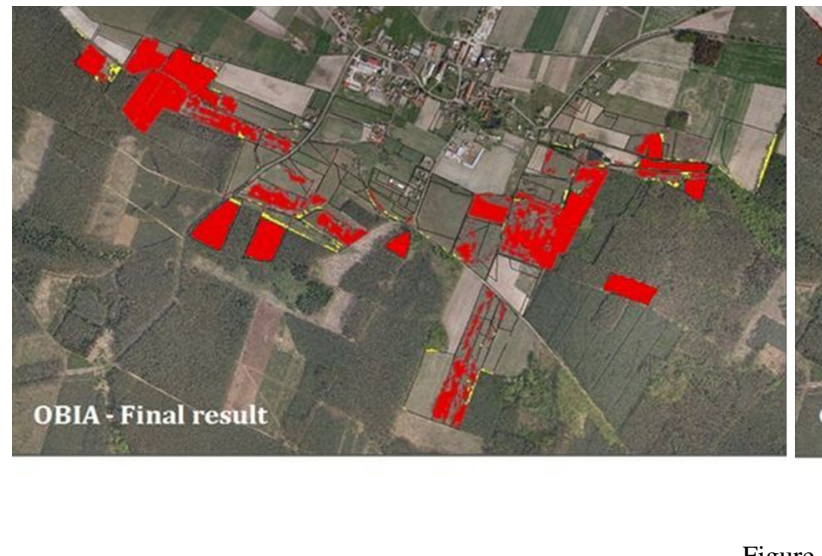

The results of OBIA classification and GIS analysis (ALS data)

Table 1

The total area of land used in the test area based on cadastral data, transformation of ALS data, OBIA classification, screen vectorization of orthophoto RGB and true orthophoto CIR (Mean and SD_calculated without cadastral data)

\begin{tabular}{llllllll}
\hline Land use & \multicolumn{1}{l}{ Total area (ha) } & & & & Mean (ha) & SD (ha) \\
\cline { 2 - 6 } & Cadastral data & ALS & OBIA & ORTHO RGB & True ortho CIR & \\
\hline Arable land (A) & $27.93(69.0 \%)$ & $16.91(41.8 \%)$ & $16.53(40.8 \%)$ & $17.34(42.8 \%)$ & $16.71(41.3 \%)$ & $16.87(41.7 \%)$ & $0.35(0.9 \%)$ \\
Meadow (M) & $2.05(5.1 \%)$ & $1.30(3.2 \%)$ & $1.29(3.2 \%)$ & $1.47(3.6 \%)$ & $1.42(3.5 \%)$ & $1.37(3.4 \%)$ & $0.09(0.2 \%)$ \\
Pasture (P) & $4.29(10.6 \%)$ & $2.45(6.0 \%)$ & $2.30(5.7 \%)$ & $2.63(6.5 \%)$ & $2.71(6.7 \%)$ & $2.52(6.2 \%)$ & $0.19(0.5 \%)$ \\
Forest (F) & $6.23(15.4 \%)$ & $19.84(49.0 \%)$ & $20.38(50.3 \%)$ & $19.05(47.0 \%)$ & $19.66(48.5 \%)$ & $19.73(48.7 \%)$ & $0.55(1.4 \%)$ \\
Total & 40.50 ha & & & & & & \\
\hline
\end{tabular}

and ALS data processing. By analysing the results of the automatic ALS data processing, nDSM representing vegetation cover above $1.0 \mathrm{~m}$ above the ground gave results closest to the results of manual photointerpretation of airborne RGB orthophotos (19.84 ha, $49.0 \%$, Table 1). For the other options of analysis: $\mathrm{nDSM}>2.0 \mathrm{~m}$ and $>3.0 \mathrm{~m}$, the presence of secondary forest vegetation in the area was respectively: 18.06 ha $(44.6 \%)$ and 16.35 ha $(40.4 \%)$.

Based on the results of presented work, it can be concluded, that the state-of-the-art remote sensing technologies can replace the operator manual works for determining the borders of the land cover (land use) classes (Bork and Su, 2007; FalKowsKi et al., 2009; Singh et al., 2012; SuZANCHI and KaUR, 2011). Pioneer work on automatic image classification was focused on the apparent spectral similarity of neighbouring pixels in optical remote sensed satellite data. With increasing spatial resolution, many neighbouring pixels in an earth observation satellite image are registered over the identical class of land cover type.
Only the spectral properties of this object might reveal right information (DE KOK and WEZYK, 2008). The previous works based on the data acquired by AISA hyperspectral scanner showed that not only the high spatial resolution is important for the land cover classification, but the high number of spectral bands as well (WEZYK and WeRTZ, 2005; Ustin et al., 2004). Modern spatial data acquisition technologies like airborne laser scanning and satellite images can be used for automatic land cover mapping. The layers representing spatial extent of various objects are very valuable, especially when the $3 \mathrm{D}$ geometrical information stored in the ALS point clouds is taken into consideration. The integration of the geometrical (ALS) and radiometric (multispectral) information make it possible to achieve high quality of the image classification (HILl et al., 2002; TOMPALSKI and WEZYK, 2012).

The automation of the ALS point clouds processing with GIS analysis and OBIA tools, allow for the obtainment of very accurate borders of the land 
cover classes compared to traditionally applied photointerpretation and "on-screen" vectorization methods, but in a more objective and efficient way. The OBIA classification of multispectral airborne orthophotomaps (RGB + CIR), together with the application of the ALS products, produces more accurate results. Integration of these two types of datasets helps to derive land cover maps with additional attributes. The use of normalized ALS point cloud data improves the quality (accuracy) of the classification as well as allows for a height differentiation in vegetation classes, e.g.: low, medium, and high, or even to distinguish single trees (CHUBEY et al., 2006; WEZYK et al., 2012a, b).

\section{Conclusions}

The secondary forest succession on abandoned arable land in Poland is very common, particularly on weak quality sandy soils and in the neighbourhood of existing forest complexes. ALS technology can provide very precise information on the dynamics of this process. It allows a significant increase of the automatic detection process and the assessment of the dynamics and subsequent phases of forest succession in areas where agriculture has stopped.

Additionally, ALS is a perfect tool for the analysis of ongoing land cover changes and can significantly help in the process of photointerpretation of airborne orthophotos generated in a standard way based on DTM, which usually leads to problems with the geometry of high objects (treetops). Subjectivity of the interpretation of airborne photo materials (2D) can be significantly limited with the support of ALS point clouds or products of their processing, like e.g. nDSM.

Thanks to the availability of ALS data in Poland (e.g., The Information System of the Protection of the Country against extraordinary threats; ISOK), the quality of spatial models and environmental decisions is gradually improving. The results of the ISOK programme, covering approximately $60 \%$ of the Polish territory with ALS data and airborne photos (and the planned continuation of the project in the years 2014-2016), can provide the means to fully automate the process for determining proper forest and succession borders. However, the automation of transforming large ALS datasets and high-resolution multispectral airborne images is still a great challenge in terms of their processing. Additionally, the technology of introducing large format digital cameras and the application of proper algorithms (stereomatching) in the first ISOK project period (2011-2013) allow the automatic generation of DSM for the areas where ALS data was not obtained. Collectively, it gives great possibilities of 3D GIS analyses and automation in determining borders of vegetation cover (land use) classes.

It can be concluded, that the remote sensing technology provides accurate information about spatial and temporal distribution of land cover classes. Combining the 2D spatial location and data with time factor enables the monitoring of vegetation changes types. The use of aerial photographs has become more popular during the last several decades. The integration of photogrammetry with other technologies, such as LiDAR, GNSS or GIS, is applied for example in the mapping of the different types of land cover (land use), soil mapping or in the forest inventory research.

Open Access This article is distributed under the terms of the Creative Commons Attribution License which permits any use, distribution, and reproduction in any medium, provided the original author(s) and the source are credited.

\section{REFERENCES}

Andersen, H. E., Reutebuch, S. E., and Mcgaughey, R. J. (2006), A rigorous assessment of tree height measurements obtained using airborne lidar and conventional field methods. Canadian Journal of Remote Sensing. 32 (5), 355-366.

Axelsson, P. (2000), DEM generation from laser scanner data using adaptive TIN models. International Archives of Photogrammetry and Remote Sensing. XXXIII/4B, 203-210.

Baldock, D., Beaufoy, G., Brouwer, F., and Godeschalk, F. (1996), Farming at the Margins: Abandonment or Redeployment of Agricultural Land in Europe. London/The Hague, Institute for European Environmental Policy (IEEP)/Agricultural Economics Research Institute (LEI-DLO).

Bergen, K.M., and Dronova, I. (2007), Observing succession on aspen-dominated landscapes using. a remote sensing-ecosystem approach. Landscape Ecology. 22, 1395-1410.

BlaschKe, T. (2010), Object based image analysis for remote sensing. ISPRS Journal of Photogrammetry and Remote Sensing 65 (1), 2-16. 
Bork, E.W., and Su J.G. (2007), Integrating LIDAR data and multispectral imagery for enhanced classification of rangeland vegetation: a meta-analysis. Remote Sensing of Environment. 111 (1), 11-24.

Bowen, M. E., McAlpine, C.A., House, A. P.N., and Smith, G.C. (2007), Regrowth forests on abandoned agricultural land: A review of their habitat values for recovering forest fauna. Biological Conservation. 140, 3-4, 273-296.

Central Statistical Office GUS (2010), http://www.stat.gov.pl/gus.

Chubey, M.S., Franklin, S.E., and Wulder, M.A. (2006), Objectbased analysis of Ikonos-2 imagery for extraction of forest inventory parameters. Photogrammetric Engineering and Remote Sensing. 72 (4), 383-394.

Commission of the European Communities (1994). CORINE Land Cover, http://www.eea.europa.eu/publications/COR0-landcover.

Ewisk, K.Y.v., Treitz, P.M. and Scott, N.A., Characterizing forest structure using a lidar derived complexity index. In: Silvilaser (ed. Popescu, S., Nelson, R., Zhao K., and A. Neuenschwander), (College Station, Texas, USA, 2009).

Falkowski, M.J., Jefreey, S., Evans, J.S., Martinuzzi, S., Gessler, P.E, and HudAK, A.T. (2009), Characterizing forest succession with lidar data: An evaluation for the Inland Northwest, USA. Remote Sensing of Environment. 113, 5, 946-956.

Finegan, B. (1984), Forest Succession. Nature. 312, 109-114.

FrY, G., and SARLÖV-HERLIN, I. (1997), The ecological and amenity functions of woodland edges in the agricultural landscape: a basis for design and management. Landscape. Urban Planning. 37, 45-55.

GAO, Y., and MAS, J.F. (2008), A Comparison of the Performance of Pixel Based and Object Based Classifications over Images with Various Spatial Resolutions. Online Journal of Earth Sciences. 2, 1, 27-35.

Glenn-Lewin, D.C., and van Der MaArel, E. Patterns and processes of vegetation dynamics in: Plant succession, theory, and prediction (ed. Glenn-Lewin, D.C., Peet, R.K., Veblen, T.T.) (Chapman \& Hall, New York, 1992) pp. 11-59.

Goluch, P., Borkowski, A., Jozkow, G., Tyмкоw, P., and Мокwa, M. (2009), Application of Digital Terrain Model generated from Airborne Laser Scanning data in Hydrodynamic Modelling. StudiaGeotechnica et Mechanica. XXXI, 3, 61-72.

Hall, F.G., Botkin, D.B., Strebel, D.E., Woods, K.D., and Goetz, S.J. (1991), Large-scale patterns of forest succession as determined by remote-sensing. Ecology. 72(2), 628-640.

Hashimoto, H., Imanishi, J., Hagiwara, A. and Morimoto, Y., Estimating Forest Structure Indices for Evaluation of Forest Bird Habitats by an Airborne Laser-Scanner. In: LaserScanners for Forest and Landscape Assessment, (ed. ThIES, M., Koch, B., Spiecker, H. and Weinacker, H.) (Freiburg, Germany, 2004).

Hay, G.J., Castilla, G., Wulder, M.A., and Ruiz, J.R. (2005), An automated object-based approach for the multi-scale image segmentation of forest scenes. International Journal of Applied Earth Observation and Geoinformation. 7 (4), 339-359.

Hill, R.A., Sмith, G.M., Fuller, R.M., Veitch, N. (2002), Landscape modeling using integrated airborne multi-spectral and laser scanning data. International Journal of Remote Sensing. 23 (11), 2327-2334.

Höfle, B., and Hollaus, M., Urban vegetation detection using high density full-waveform airborne LiDAR data - Combination of object-based image and point cloud analysis In: ISPRS Technical Commission VII Symposium, 100 Years ISPRS, (ed. WAGNER W. and Székely B.) (Advancing Remote Sensing Science, Vienna, Austria 2010).

Hollaus, M., Dorigo, W., Wagner, W., Schadauer, K., Hăśfle, B., and MAIER, B. (2009), Operational wide-area stem volume estimation based on airborne laser scanning and national forest inventory data. International Journal of Remote Sensing. 30 (19), 5159-5175.

Holmgren, J., and Jonsson T. (2004), Large Scale Airborne Laser Scanning of Forest Resources in Sweden. Proc. of the ISPRS working group VII/2 "Laser-Scanners for Forest and Landscape Assessment". Freiburg, Germany: International Archives of Photogrammetry, Remote Sensing and Spatial Information Sciences. XXXVI, 8/W2, 157-160.

Hyyppä, J., Hyyppä, H., Litkey, P., Yu, X., Haggrén, H., RönNholm, P., Pyysalo, U., Pitkanen, J., and Maltamo, M. (2004), Algorithms and methods of airborne laser-scanning for forest measurements. International Archives of Photogrammetry, Remote Sensing, and Spatial Information Sciences. 36, 8, $1682-1750$.

DE Koк, R., Wezyk, P., Principles of full autonomy in image interpretation. The basic architectural design for a sequential process with image objects. In: Object-Based Image Analysis. Lecture Notes in Geoinformation and Cartography (ed. BLASChKe, TH., Lang, S., HaY, G.J) (Springer Berlin Heidelberg, 2008) pp. 697-710.

de Koк, R., Wezyк, P., and Weidenbach, M. The role of edge objects in full autonomous image interpretation, In: Pixels, Objects, Intelligence: Geo-Object Based Image Analysis for the 21st Century (ed. Hay, G.J., Blaschke, T., Marceau, D) (GEOBIA, University of Calgary, Calgary, Alberta, Canada, 2008)

Lefsky, M.A., Cohen, W.B., Parker, G.G. and Harding, D.J. (2002), Lidar Remote Sensing for Ecosystem Studies. BioScience. 52/1, 19-30.

Lindner, M., Lasch, P., and Cramer, W. (1996), Application of a forest succession model to a continentality gradient through Central Europe. Climatic Change. 34, 2, 191-199.

LowICKI, D. (2008), Land use changes in Poland during transformation: Case study of Wielkopolska region Landscape and Urban Planning. 87, 279-288.

McGaughey, R. J. (2007), Fusion/LDY: Software for LiDAR data analysis and visualization. (Software manual. USDA Forest Service. Pacific Northwest Research Station.

McGaughey, R. J., Carson, W., Reutebuch, S., and Andersen, H.E. (2004), Direct measurement of individual tree characteristics from lidar data. Proceedings of the Annual ASPRS Conference. Denver. American Society of Photogrammetry and Remote Sensing.

Mücke, W., Hollaus, M. and Prinz, M., Derivation of 3D landscape metrics from airborne laser scanning data. Silvilaser Freiburg, Germany, 2010.

Nyström, M., Holmgren, J., and Olsson, H. (2012), Prediction of tree biomass in the forest-tundra ecotone using airborne laser scanning. Remote Sensing of Environment, 123, 271-279.

Oikonomakis, N., and Ganatsas, P. (2012), Land cover changes and forest succession trends in a site of Natura 2000 network (Elatia forest) in Northern Greece. Forest Ecology and Management, 285, 1, 153-163.

Prévosto, B., Kuiters, L., Bernhardt-Rémermann, M.; Délle, M., Schmidt, W., Hoffmann, M., Uytvanck, J., Bohner, A., Kreiner, Daniel, Stadler, J., Klotz, S., and Brandl, R. (2011), 
Impacts of Land Abandonment on Vegetation: Successional Pathways in European Habitats. Folia Geobotanica. 46, 303-325.

Ruskule, A., Nikodemus, O, Kasparinska, Z., Kasparinskis, R., and BrūMelis, G. (2012), Patterns of afforestation on abandoned agriculture land in Latvia. Agroforestry Systems. 85, 2, 215-231.

Rutzinger, M., Höfle, B. and Pfeifer, N., Detection of high urban vegetation with airborne laser scanning data, (ForestSAT07, Montpellier, 2007).

Singh, K., Vogler, J., Shoemaker, D., and Meentemeyer, R. (2012), LiDAR-Landsat data fusion for large-area assessment of urban land cover: Balancing spatial resolution, data volume, and mapping accuracy. ISPRS Journal of Photogrammetry and Remote Sensing. 74, 110-121.

STERENCZAK, K. (2009), Single tree detection based on airborne LIDAR (ALS) data. Annals of Geomatics. VII, 2 (32), 121-126.

Susyan, E.A, Wirth S., Ananyeva, N.D, and Stolnikova, E.V. (2011), Forest succession on abandoned arable soils in European Russia - Impacts on microbial biomass, fungal-bacterial ratio, and basal $\mathrm{CO}_{2}$ respiration activity. European Journal of Soil Biology. 47, 3, 169-174.

SuZANCHI, K., and KaUR, R. (2011), Land use land cover change in National Capital Region of India: A remote sensing \& GIS-based two decadal spatial-temporal analyses. Procedia - Social and Behavioral Sciences. 21, 212-221.

Tompalski, P., WezyK, P. (2012), LiDAR and VHRS data for assessing living quality in cities - an approach based on 3D spatial indices. International Archives of the Photogrammetry, Remote Sensing and Spatial Information Sciences, Volume XXXIX-B6, 2012. XXII ISPRS Congress.

Ustin, S.L., Roberts, D.A., Gamon, J.A., Asner, G.P., Green, R.O. (2004), Using imaging spectroscopy to study ecosystem processes and properties. BioScience 54 (6), 523-534.

WezyK, P., Borowiec, N., Szombara, S., and WanczyK, R. (2008a), Generation of digital surface and terrain models of the Tatra mountains based on airborne laser scanning (ALS) point cloud. Archives of Photogrammetry, Cartography and Remote Sensing. 18, 651-661.

WEZYK, P., and DE KoK, R., Automatic mapping of the dynamics of forest succession on abandoned parcels in South Poland. In: Angewandte Geoinformatik (ed. STROBL et al.) (Herbert WichmanVerlag. Heidelberg, 2005) pp. 774-779.

WezyK, P., Koziol, K., Glista, M., and Pierzchalski, M. (2007), Terrestrial laser scanning versus traditional forest inventory. First results from Polish forests. IAPRS Volume XXXVI, Part 3/W52. ISPRS Workshop on Laser Scanning 2007 and SilviLaser 2007, Espoo, September 12-14, 2007, Finland, 424-429.

Wezyk, P., Pierzchalski, M., Szwed, P., Wojtowicz-Nowakowska, A., and Mlost. J. (2012a), Enhancing the OBIA classification of multispectral aerial orthoimages using airborne laser scanning data. Archives of Photogrammetry, Cartography and Remote Sensing. 23, 467-476.

Wezyk, P., Pierzchalski, M., Szwed, P., Wojtowicz-Nowakowska, A., and Mlost, J. (2012b), Land cover mapping based on OBIA of Rapid-eye satellite data. Archives of Photogrammetry, Cartography and Remote Sensing. 23, 489-500.

Wezyк, P., and Pyrkosz, R. (1999), The use of clearings in the Gorce Mountains in the years 1954-1997 on the basis of photogrammetric analyses of aerial photos. Archives of Photogrammetry, Cartography and Remote Sensing. 9, 223-232.

Wezyk, P., Szostak, M., and Tompalski, P. (2009), Comparison of the accuracy of the "PHOTO" check method with automatic analysis based on ALS data for direct control of subsidy payments. Archives of Photogrammetry, Cartography and Remote Sensing. 20, 445-456.

WeZyK, P., Szostak, M., and Tompalski, P. (2012), Vertical biomass and volume profile of the Scots Pine (Pinus sylvestris L.) in the Niepolomice Forest (Poland) based on the terrestrial laser scanning data - a case study. Annals of Geomatics. 10, 5(55) 79-89.

Wezyk, P., Szostak, M., Tompalski, P., and Zajaczkowski, G. (2010), The role of Airborne Laser scanning in updating and revising GIS databases - a case study in the Polish State Forest (Chojna District), Proceedings of Silvilaser 2010, the 10th International Conference on LiDAR Applications for Assessing Forest Ecosystems.

Wezyk, P., Tompalski, P., Szostak, M., Glista, M., and PierzCHALSKI, M. (2008b), Describing the selected canopy layer parameters of the Scots Pine stands using ALS data; 8th international conference on LiDAR applications in forest assessment and inventory. Sept. 17-19. 2008-Edinburgh, UK. ISBN 978-085538-774-7 (CD), 636-645.

WeZYK, P., WeRTZ, B., Forest map revision using the hyperspectral scanner AISA images. In: Imaging Spectroscopy. New Quality in Environmental Studies. (ed. ZAGAJEWSKI and SobCZAK) (Warsaw University, 2005) pp. 687-699.

Zhang, J.T. (2005), Succession analyses of plant communities in abandoned croplands in the Eastern Loess Plateau of China. Journal of Arid Environments. 63, 2, 458-474. 